\title{
Methodological Guidelines for the Sustainable Development of the Bulgarian Touristic Resorts through Reducing the Harmful Impact of Transport
}

\author{
Elenita Velikova ${ }^{1,}{ }^{*}$ \\ ${ }^{1}$ Department of Economy of tourism, UNWE, 1700 Sofia, Bulgaria
}

\begin{abstract}
The achievement of sustainable development of Bulgarian tourist resorts is questionable after the European Commission has put Bulgaria's two-month ultimatum to prove that it can deal with the problem of dirty air. Tourism is a sector that is accused of violating sustainable development due to its many negative environmental impacts. A significant part of the harmful impact is due to the transport used to reach the desired destination and the movement itself. Sustainable development is a key objective of the EU and Bulgaria should not lag behind in terms of the essential indicators for its achievement. This publication aims to propose effective measures to reduce the harmful impact of passenger transport on the environment by establishing sustainable transport practices in touristic resorts. The environmental component of sustainable development is among its main priorities. Based on expert analysis of Bulgarian touristic resorts, our own research and experience in the studied subject will offer effective measures to increase their sustainability by reducing the harmful impact of transport on the environment.
\end{abstract}

\section{Introduction}

Sustainable development is a topic of importance to the public since the 1990s as a result of human's threatening impact on Planet Earth. Demand for approaches that increase economic growth without restricting future generations' access to available resources is a priority task in many countries' economies. Tourism is an activity that is no exception in this manner. Since the UN Conference on Environment and Development held in Rio de Janeiro in 1992, approaches have been sought to make the tourism sector contribute to the sustainable development of the regions.

The interest in the development of this topic is motivated by the fact that the issues of mobility and transport and their impact, or even their contribution to the sustainable development of tourism, are poorly addressed or insufficiently explored in the existing specialized literature on tourism in Bulgaria. Even in the National Strategy for Sustainable Tourism Development in Bulgaria 2014-2030, no attention has been paid to this problem. There is an overview of the transport infrastructure in the country and the preferences of the tourists to the variety of transport to reach the tourist destinations by 2030 but the opportunities for achieving sustainable tourism development by ensuring sustainable mobility or ecological transport is not the subject of the analyzes or part of the strategic measures. That is why the purpose of this publication is to provide effective guidelines on limiting the harmful impact of passenger transport on the environment by establishing sustainable transport practices in tourist destinations and thus contributing to the sustainable development of tourism. In order to achieve the stated objective, the state of the Bulgarian tourist resorts will be analyzed in relation to established sustainable transport practices, the current negatives of mobility and transport, hindering the sustainable tourism will be established, and on this basis mechanisms for overcoming or minimizing the harmful impact of transport based on expert analysis, personal research and experience.

\section{Literature review}

Sustainable development of tourism and sustainable tourism are terms that have not yet been found in the specialized literature. The concept of "sustainable development" becomes universal after the publication of the report "Our Common Future" by the World Organization for Environment and Development (1988). Since then, attempts to define concepts have focused on several main areas.

Sustainability should be understood as the ability of systems (environmental, economic and social) to compensate for emerging fluctuations and imbalances [1]. A wider understanding of the concept of sustainable development combines a number of ethical norms such as well-being, humane treatment and wealth distribution, recognizing the limited possibilities of nature to regenerate human embezzlement and disturbances.

Corresponding author: evelikova@unwe.bg 
In general, sustainability is associated with the ability to preserve a particular behaviour of the system, with its combined impact on the internal and external environment [2]. Sustainable development is a common goal of the EU, including our country. Sustainable development should cover all sectors of the economy and is not an isolated phenomenon within a country.

Sustainable tourism development requires management not only of human, physical and financial capital, but also of environmental assets that are not substitutable, are not unlimited and without which the application of others would lose its meaning. Sustainable tourism should seek to benefit from natural resources in a way that meets human needs while preserving the natural balance in the environment. These needs must be able to be satisfied in the future. Sustainable tourism evolves on the basis of harmony between resource use and conservation through the integration of the local community. In all definitions of sustainable development and sustainable tourism, the issue of preserving the ecological balance is a main subject.

Sustainable tourism is not a specific type of tourism, but a way of managing tourism at all. As a starting point in our analyzes, we adopt the definition of sustainable tourism defined by the World Tourism Organization (UNWTO): Tourism envisaged as leading to the management of all resources in such a way that economic, social and aesthetic needs can be fulfilled while maintaining cultural integrity, essential ecological process, biological diversity, and life support systems [3]. At the beginning of the concept of sustainable development erroneously as such types of tourism are considered the ecological, the alternative, the soft, the green, etc. The idea of the 21 st century is for all types of tourism to be sustainable.

According to the World Tourism Organization (2004), the main parameters of sustainable tourism, its implementation and management, are applicable to all forms of tourism and all types of destinations, including mass tourism and the different segments of tourist niches. The principles of sustainability relate to the economic, socio-cultural and environmental impacts of tourism and to the appropriate balance between these three dimensions in order to ensure long-term sustainability. Sustainable tourism should therefore:

- Realize the optimal use of environmental resources, which is a key element in the development of tourism, maintaining ecological balance and helping to preserve natural heritage and biodiversity.

- Respect the socio-cultural identity of host communities, to preserve cultural heritage, traditional values and to contribute to intercultural understanding and tolerance.

- Provide long-lasting activities that bring socioeconomic benefits equitably distributed amongst all actors, including a stable employment base, profit opportunities and social services for the host community, helping to eradicate poverty [4].
A key part of the definitions is the ecological component of sustainable development. This gives us grounds to look for opportunities to minimize the harmful impact of tourism on the environment in order to ensure its sustainable development. In this respect, one of the main critics of tourism is related to the means of transport used to reach the desired destination. That is why it is interesting for us to see how the harmful impact of transport on the environment can be minimized.

\section{Methodology of research}

The subject of research in this publication is sustainable tourism, and the subject of the analysis is how it can be achieved through environmentally friendly transport practices. According to us, the opportunities to reduce the harmful impact of passenger transport on the environment will greatly increase the sustainability of tourism in the long run. Ensuring environmental equilibrium is a complex task that depends on the efforts of all stakeholders.

There are studies that are trying to identify opportunities for sustainable transport. According to them, the sustainable development of transport is an essential necessity for the successful economic development of the country and is a factor for the improvement of the state of the environment and raising the living standards of the population. The development of sustainable transport is a difficult task, requiring significant investment and strategic, organizational and technical measures [5]. Therefore, we believe that if we combine the concept of sustainable transport development with the development of tourism, we can reduce the harmful impact of tourism and transport on the environment, which in turn will lead to sustainable development of the two sectors, with equal other conditions.

A starting point in our analyzes to reduce this harmful impact will be indicators that determine the choice of tourists on a means of transport. It depends on:

- the total duration of the journey to the destination, especially for short stays;

- travel costs (direct costs are taken into account by the consumer);

- adequate transport services, luggage transport, bicycle, etc ;

- the availability of and information regarding local public transport;

- providing a direct connection without being moved;

- the availability of means of transport in the region [6].

Exploring these dominant factors in choosing a means of transport during a vacation in Bulgaria is a crucial factor in ensuring sustainable mobility, and this provides an opportunity for sustainable tourism development. If we are able to meet the needs of the individual consumer when choosing a mode of transport and a means of transport, we will make a decisive step forward towards sustainable destination development. 
Ever since the emergence of the concept of sustainability at its core has been laid the principle that change has to come from the change of consciousness of the individual. Expert studies show that there is already a significant increase in consumer self-awareness with regard to the demand for sustainable tourism products, but the response of the business is far from sufficient to meet this demand.

The absolute travel growth over recent decades has been marked by several distinct trends:

- increasing the number of trips and reducing the length of stay;

- increased leisure time mobility

- numerous weekend tours and one-day excursions;

- growth of the number of second homes for recreation or tourism;

- spatial and temporal concentration of tourist flows during the summer and winter season or at weekends.

These trends unambiguously show that the development of tourism will continue, thus increasing the use of transport. However, so far little research has been done on the connection between transport and tourism. Our studies of the Bulgarian literature on transport and tourism have identified a lack of research into the possibilities of reducing the harmful impact of transport on the environment in order to ensure the sustainable development of tourism.

There are studies that are trying to identify opportunities for sustainable transport. According to them, the sustainable development of transport is an essential necessity for the successful economic development of the country and is a factor for the improvement of the state of the environment and raising the living standards of the population. The development of sustainable transport is a difficult task, requiring significant investment and strategic, organizational and technical measures [5]. Therefore, we believe that if we combine the concept of sustainable transport development with the development of tourism, we can reduce the harmful impact of tourism and transport on the environment, which in turn will lead to sustainable development of the two sectors, with equal other conditions.

In 2014, the European Commission is developing a "European system of indicators for tourism. Set of sustainable destination tools ". In its view, analyzing the use of environmentally friendly transport options to reduce trafficking should be the starting point for defining local transport policies [7]. Therefore, the aim is to reduce the harmful impact of transport by analyzing its use by tourists. The information gathered on the proposed basic and additional criteria and indicators is important, but it does not provide information on how we can tackle the reduction of emissions and ensuring sustainable development in the destination under consideration. After its collection, it is necessary to develop effective measures to overcome the harmful impact of transport.

\section{Results of the research}

Analyzes so far have shown that achieving a sustainable tourism development by reducing the harmful impact of the means of transport used in tourist trips is a complex task. In order to provide effective mechanisms for resolving it further, we will identify the current negative impacts of increased mobility and transport, hampering sustainable tourism. On this basis, we will offer solutions to overcome or minimize the harmful impact of transport when using it for tourist trips, which we believe will increase the sustainability of tourism.

\subsection{State of Tourism and Tourist Resorts in Bulgaria}

Tourism is gaining ever greater economic importance on a global scale. The unprecedented development of tourism, however, has a number of negative consequences. Huge carbon dioxide emissions from international air travel, polluted environment and inhumane working conditions in tourist areas - these are just some of the catastrophic consequences of mass tourism. As a result of these consequences, alternatives to mass tourism have begun to be sought, with the aim in the 21 st century that all forms and types of tourism should be sustainable. As we have emphasized, our goal is to reduce the harmful impact of tourism on the environment by minimizing the impact of transport. This can be achieved by providing environmentally friendly forms of transport or increasing the sustainability of tourist trips.

Travel and leisure travel today account for $40 \%$ of all journeys and $60 \%$ of mileage, compared to $30 \%$ in the 1960s. Travel estimates are expected to increase by 15 to $29 \%$ by 2030 . While leisure travel will increase from 26 to $31 \%$ and travel by 9 to $46 \%$ [8].

The development of tourism in our country is also interesting. The statistics on the state of tourism in Bulgaria in 2017 show that Bulgarian citizens have made a total of $\mathbf{6 , 2 2 7 , 6 2 3}$ trips abroad for all types of purposes. The growth compared to 2016 is $\mathbf{1 5 . 5 \%} 8.883$ million foreign tourists have visited Bulgaria in 2017. Compared to 2016 , the total number of tourists over 15 years has increased by $11.5 \%$. The purpose of the majority of tourist trips in the country and abroad is rest. [9].

Figure 1 shows that the number of tourists arriving in Bulgaria has increased steadily in recent years, and Table 1 shows that the majority of these tourists are from neighbour countries.

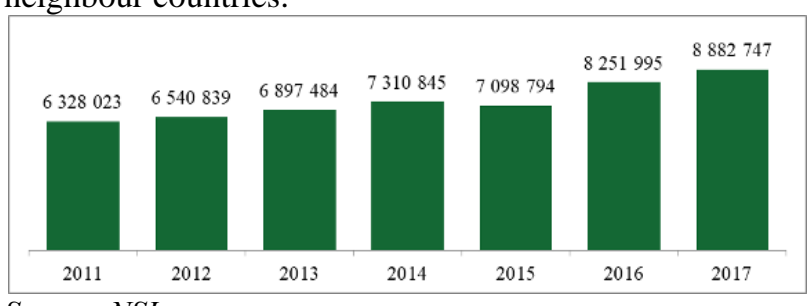

Source: NSI

Fig. 1. Travel visits of foreigners to Bulgaria (number) 
Table 1. Travel visits of foreigners to Bulgaria 2017/2016

\begin{tabular}{|c|c|c|c|c|}
\hline & COUNTRY & Number & $\begin{array}{c}\text { Change } \\
\text { (number) }\end{array}$ & $\begin{array}{c}\text { Change } \\
(\%)\end{array}$ \\
\hline \multicolumn{2}{|c|}{ Total } & 8882747 & 630752 & 7,6 \\
\hline 1 & GREECE & 1157622 & 90517 & 8,5 \\
\hline 2 & ROMANIA & 1139189 & 42315 & 3,9 \\
\hline 3 & GERMANY & 870448 & 43509 & 5,3 \\
\hline 4 & TURKEY & 636046 & 70678 & 12,5 \\
\hline 5 & RUSSIA & 557915 & -22087 & $-3,8$ \\
\hline 6 & MACEDONIA & 545431 & 17767 & 3,4 \\
\hline 7 & SERBIA & 394162 & 19346 & 5,2 \\
\hline 8 & POLAND & 394082 & 28258 & 7,7 \\
\hline \multirow[t]{2}{*}{9} & UNITED & & & \\
\hline & KINGDOM & 338114 & 64981 & 23,8 \\
\hline 10 & UKRAINE & 305486 & 39774 & 15,0 \\
\hline
\end{tabular}

The rapid growth of the various economic measures of the tourism industry has been a driver of strong investment interest in the sector and boom in the construction of hotel infrastructure [10]. Over the past year 3331 places of accommodation with over 10 beds have been working in Bulgaria - hotels, motels, campsites, chalets and others. The number of rooms in them is a little over 140000 , and the beds -328000 . The total number of overnight stays in all places of accommodation in 2016 is 25.2 million, or $17.7 \%$ more than the previous year. The trend for more overnight stays in high-end hotels is confirmed. In 2016 hotels with 4-5 stars have accounted for $66.2 \%$ of the total number of overnights stays by foreign citizens and $31.5 \%$ for Bulgarians. 3-star places have reported a $25.1 \%$ of overnight stays for foreigners and $29.1 \%$ for Bulgarians. [11].

The tourist function is developed in many Bulgarian towns and villages due to the preserved architectural, cultural and historical value in them. On the territory of Bulgaria are situated many different resorts according to their function. On the Black Sea coast are the resorts: "Rusalka", "Albena", Kranevo, "Golden Sands", "Riviera", "Chaika", "Sunny day", "St. St. Constantine and Elena ", Obzor, Elenite, Vlas, Sunny Beach, Dune, Nessebar, Ravda, Kiten, Pomorie, Primorsko, Chernomorets, Sozopol, Lozenets, Tsarevo, Ahtopol, Sinemorets and others. In addition to the sea recreational tourism on the Bulgarian Black Sea coast sports, congress, event, gambling, healing and many other types of tourism are practiced. The most developed and with international importance are the resorts "Sunny Beach", "Golden Sands", "Albena", Balchik, Pomorie, Nessebar and Sozopol.

Our mountain resorts are Pamporovo, Borovets and Bansko. The fastest growing mountain resort in Europe is Bansko. In addition to having world-class ski slopes, Bansko has over 140 cultural monuments. Great mountain conditions are offered by the mountain resorts: Malyovitsa, Panichishte, Batak, Ribaritsa, Chepelare, Yundola, Belmeken, Predel, Semkovo and Aleko. They are of national and local importance.

Bulgaria also has excellent spa, spa and wellness resorts: Hissar, Velingrad (Spa capital of the Balkans),
Sandanski, Bankya, Kyustendil, Narechen, Pavel Banya, Kostenets, Varshets, Bourgas Mineral Baths, Momin Prohod, Sliven Mineral Baths, Stara Zagora Mineral Baths, Haskovo Mineral Baths, Sapareva Banya, Banya, Teteven, Tryavna, Apriltsi, Kotel, Elena, Govedartsi, Dryanovo. Our country ranks second in the wealth of available mineral resources after Iceland.

By biodiversity, Bulgaria ranks second in Europe. In the country three national ones - Pirin, Rila, Central Balkan and 11 nature parks have been established. In order to protect biodiversity, 89 reserves were created (17 of which were declared biosphere by the UNESCO Human and Biosphere Program) and 2234 nature sites were declared. Two of the natural sites - Pirin National Park and Srebarna Reserve are included in the UNESCO World Heritage List.

\subsection{Transport services for tourist trips}

International passenger trips to and from Bulgaria are mainly served by car, bus (from neighbouring and nearby countries) and air transport. Vehicle transport occupies an important place in short-haul operations [12]. Experience shows that using a private car to travel to the desired tourist destinations is the least environmentally friendly. Gatovsky analyzes different options for reducing emissions from passenger cars by replacing them with electric, hydrogen, fuel cell cars, hybrid-powered cars, and more [13]. These new opportunities will allow the reduction of the harmful impact of road transport when used for tourism purposes. Consequently, further development of technology is one of the main prerequisites for ensuring sustainable transport.

Our surveys show that tourists from neighbour countries arrive mainly with cars. Some of the arrivals from Russia and Ukraine also use cars because they consider this mode of transport to be more convenient. To a large extent they have a second home in Bulgaria, which they use for tourism. The rest, as well as tourists from Germany, Great Britain and Poland, enjoy air transport.

Despite the wide variety of settlements and resorts in Bulgaria in terms of their importance and international development, there is still more to be achieved. The winter resort of Bansko and the summer resort "Sunny Beach" are fully developed and exhausted. They also take on a large part of the arriving international tourists. On the basis of the indicators for selecting a means of transport to arrive in Bulgaria, we will take the opportunity to reduce the harmful impact of transport and the potential for sustainable development of the Bulgarian tourist resorts. The results are summarized in Table 2.

Table 2. Potential possibilities for reducing the harmful effect of transport

\begin{tabular}{cc}
\hline $\begin{array}{c}\text { Factors for selecting a } \\
\text { vehicle }\end{array}$ & $\begin{array}{c}\text { State of Bulgarian touristic } \\
\text { resorts }\end{array}$ \\
\hline - $\begin{array}{cc}\text { total journey time to the } \\
\text { destination, especially for } \\
\text { short stays; }\end{array}$ & $\begin{array}{c}\text { the duration of the trip to } \\
\text { Bulgaria is within } 2 \text { to } 5 \text { hours } \\
\text { maximum, whether it is a }\end{array}$ \\
\hline
\end{tabular}




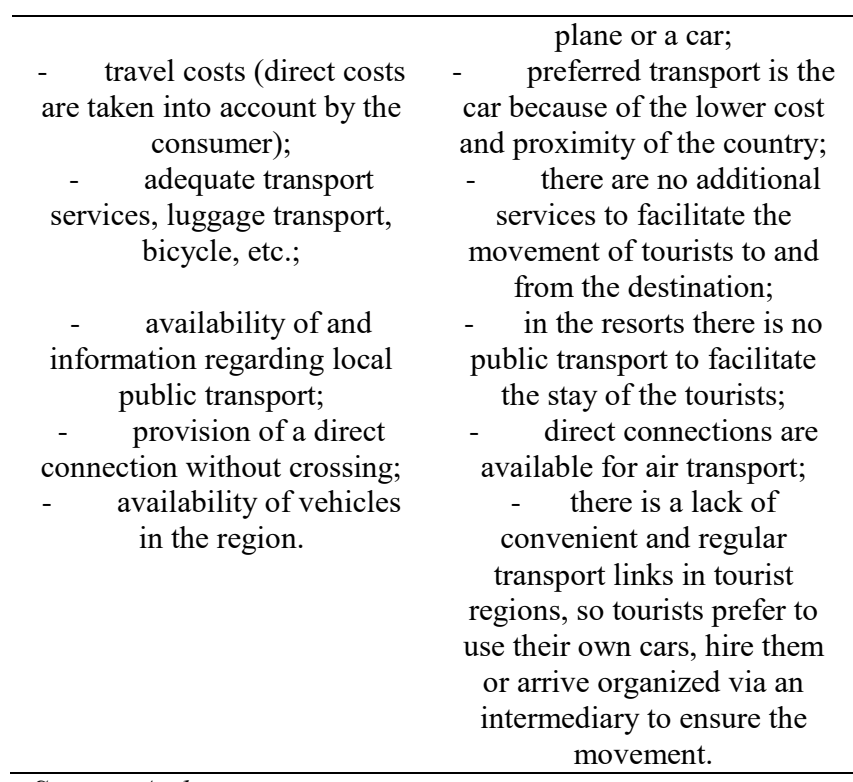

Source: Author

Regarding the environmental characteristics of sustainable tourism in its direct connection to sustainable transport, we can say that it:

- Characterized by a good public transport offer for travel to and from the destination as well as the destination itself;

- Compensates for carbon dioxide emissions from travel by supporting climate protection projects;

- Encourages tourists to stay longer in distant destinations to reduce the frequency of trips to them;

- Uses renewable energy resources in the implementation of transport services;

- There is an operational concept of infrastructure and buildings. This ensures that resources, especially water and energy, are used effectively and prevent unnecessary use of resources;

- Reduces waste, has proper waste management and proper waste management;

- Takes into account the conservation of biodiversity in destinations;

- Ensures landscaping, valuable urban structures and cultural resources [14].

\subsection{Solutions to improve the sustainable development of tourism}

One solution, as mentioned earlier, is to combine sustainable transport with sustainable tourism. This is also the goal of European transport policy - building a sustainable transport system that meets the economic and social needs of society. Recent studies in the European Union related to transport development are structured in four main target areas. First of all, reducing the harmful impact of transport on the environment, including noise and emissions, improving safety and security of transport, increasing the mobility of people and goods and increasing the competitiveness of transport [15].

The study of literature shows that there are six options for sustainable transport design: development and use of new technologies; improving public transport; a stronger environmental orientation for citizens, promoting sustainable land-use planning, including transport infrastructure; the expansion of information and communication technologies and the use of market-based instruments to influence consumers and businesses [16]. Ensuring sustainable transport in resort areas will lead to the intensification of sustainable travel trips.

The greatest negative impact of tourism on the environment is due to the traffic caused by the arrival and departure. Efforts must therefore be directed towards this area. A crucial role here belongs to public transport. In order to ensure sustainable development, it is necessary to provide a well-developed and integrated public transport system with clean and comfortable buses.

We could summarize that tourist trips are a dynamically developing segment of the transport market, which in its essence contributes significantly to resource consumption and pollution. Since people accept mobility as a means of achieving self-realization and personal development, control measures are perceived as limiting personal possibilities for action. Moreover, the elasticity of the demand for the transport service is relatively low. At the same time, destinations are sensitive to all kinds of impacts, as they fear that the measures could lead to a decrease in visitors and thus cause negative regional economic impacts. Therefore, the experience so far has shown that local project measures have been implemented in this area to reduce the negative effects of tourist traffic "on the ground". In our view, the induction of changes in behaviour in the long run requires increasing self-awareness in each individual tourist, engaging the academic community with sustainable development issues, integrating a transport policy appropriate to the locality and destination that meets the needs and requirements of the target groups, innovative technologies in transport infrastructure to reduce harmful environmental impacts. Therefore, a comprehensive approach is needed to meet the needs in the long term.

\section{Conclusions}

In order to be able to determine to what extent environmental indicators have been achieved in the use of transport in tourism, we have to answer the following questions regarding accessibility to, to and from destinations:

- Has the transport pressure on the destination caused by tourism been reduced?

- Do tourists travel with more sustainable means of transport?

- Is the length of stay longer? Are more day visitors available or are there long stays? 
- What are the main means of transport used by tourists during their stay in the destinations?

By using the latest technologies with high resource and energy efficiency, redistribution of arrivals by different modes of transport, where soft mobility and public transport are preferable to private transport, it is possible to take measures to reduce resource consumption, which will ensure their preservation for future generations. Still to a large extent sustainable development is linked to ecological equilibrium. This highlights the issues of its provision.

Two of the cornerstones of sustainable destination development are the development of new technologies in the delivery and organization of transport infrastructure and the change in travel behaviour. The idea of sustainable development requires us as tourists to radically rethink our behaviour. There is also a clear political will. To overcome the massive nature of private transport, it is not enough just to improve public transport. Energy support for innovative solutions in the transport sector can contribute to the economic and tourist attractiveness of destinations.

\section{References}

1. В. Банабакова, И Йонова, Устойчивото развитие и проблемите на българския туризъм (Управление и устойчиво развитие 1/2007(16) 366-375 p 366 (2007)

2. Зл. Караджова, Концепцията за управление на тоталното качество като основа за устойчиво развитие на отрасъл „Туризъм“ (Cn. Управление и устойчиво развитие 1-2/2005 (12) 403-406 р 403 (2005)

3. UNWTO 2018 Sustainable Development of Tourism Available from: sdt.unwto.org/content/about-us-5 [accessed Jul 2018]

4. СОТ 2004 Наръчник Добри Практики за Устойчиво Развитие в Туризма Available from: https://eurekainstitute.eu/tourist/images/Infmaterials/Narachnik.pdf [accessed Jul 2018]

5. S. Tzvetkova, Policies for the Stable Development of Automobile Transport (Management and Stable Development Journal, University of Forestry, Year 19, Vol. 65, Issue 4) pp 48-51 (2017)

6. M. Kovačić, T. Milošević, Interdependence of Transport and Tourism (Pomorski zbornik 52 (2016) p 99-111 (2016)

7. Европейска комисия 2014 Европейска система от показатели за туризма. Набор от инструменти за устойчиви дестинации Available from: https://publications.europa.eu/en/publicationdetail/-/publication/6f6546d4-a9a9-458d-8878b7232e3a6b78/language-bg [accessed Jul 2018]

8. R. Matos-Wasem, Reisemobilität und Nachhaltigkeit in den Schweizer Alpen Available from: https://www.mobilservice.ch/de/home/praxis-9.html [accessed Jul 2018].

9. NSI 2017 Tourist Trips and Tourism Expenses of the Population Available from: http://www.nsi.bg/ [accessed Jul 2018].

10. Др. Стефанов, Състояние и проблеми пред хотелската недвижима собственост в България Търговският и туристическият бизнес в условия на интелигентен, устойчив и приобщаващ, растеж Акад. издателство "Ценов" Свищов 232-238 (2016)

11. Evg. Marinova, Tourism in Bulgaria with Sustainable Growth Over the Last Eight Years Available from: http://www.investor.bg/ ikonomikai-politika/332/a/turizmyt-v-bylgariia-s-ustoichiv-rystprez-poslednite-osem-godini-236617 [accessed Jul 2018]

12. Д. Йорданов, Ролята на транспорта за развитието на туризма в България ("Икономика u управление”, Год. VIII, брой 4/ 2012) р 51-57 Available from: http://fe.swu.bg/en/wpcontent/uploads/07-4-2012.pdf [accessed Jul 2018]

13. И. Гътовски, Повишаване на енергийната ефективност на масовия градски транспорт чрез внедряване на иновативни технологии (Национална конференция: Икономически предизвикателства: Растеж, дисбаланси, устойчиво развитие) София: Издателски комплекс-УНСС (2016)

14. GSTC Global Sustainable Tourism Criteria. Global Sustainable Tourism Criteria for Destinations Available from: http://www.gstcouncil.org/sustainable-tourism-gstccriteria/criteria-for-destinations.html [accessed Jul 2018]

15. Sv. Tzvetkova, Policies for the Stable Development of Automobile Transport (Management and Stable Development Journal, University of Forestry, Year 19, Vol. 65, Issue 4/2017) p 48-51 (2017)

16. Holden, Achieving Sustainable Mobility: Everyday and Leisure-time Travel in the EU Aldershot: Ashgate. (2007) 